\title{
Ewa Kula, Marzena Pękowska, Polityczno-światowy wymiar edukacji ustawicznej w szkolnictwie wyższym. Podręcznik aka- demicki, Wydawnictwo Uniwersytetu Jana Kochanowskiego, Kielce 2015, ss. 90.
}

W omawianej publikacji zespołu autorskiego Ewa Kula, Marzena Pękowska znajdujemy interesujące poznawczo studium monograficzne dotyczące edukacyjnych i społeczno-politycznych aspektów kształcenia ustawicznego w uczelniach wyższych. Całość została pomyślana jako podręcznik akademicki i przygotowana z myślą o studentach pedagogiki, aczkolwiek może też stanowić kompendium wiedzy na ten temat dla studentów innych kierunków czy innych przedstawicieli środowiska akademickiego (wykładowców, administracji) i otoczenia społecznego uczelni.

Przygotowując podręcznik, Autorki oparły się, jak same wskazują we Wprowadzeniu, na własnych, publikowanych w kraju, jak i za granicą, artykułach. Wykaz 23 wykorzystanych w książce prac własnych - wydanych, dodajmy, po polsku, rosyjsku i angielsku - został pomieszczony na końcu podręcznika (s. 75-78). Analiza listy jedynie utwierdza w przekonaniu o bardzo dobrym przygotowaniu merytorycznym Autorek do podręcznikowego opracowania tytułowego zagadnienia. Oprócz szerzej znanych już wcześniej w Polsce: wieloautorskiej monografii z autorskim udziałem i pod redakcją duetu Autorek pt. Szkolnictwo wyższe w Europie i w Polsce w świetle założeń i realizacji procesu bolońskiego (Wszechnica Świętokrzyska, Kielce 2004, s. 312) oraz artykułu opublikowanego w jednym z ostatnich numerów „Rocznika Andragogicznego” (E. Kula, M. Pękowska, Rola szkolnictwa wyższego $w$ rozwoju ksztatcenia ustawicznego w Europie i w Polsce. Próba porównania, „RA” 2012, [t. 19], s. 272-285) czy dwóch tekstów ogłoszonych w Moskwie i w Rostowie nad Donem, znajdujemy bowiem na liście aż kilkanaście artykułów i dwie książki opublikowane we współpracy $\mathrm{z}$ jednym $\mathrm{z}$ bardziej znaczących w Europie ośrodków andragogicznych kierowanym przez prof. Mikołaja Łobanowa, czyli Uniwersytetem im. Aleksandra Puszkina w Pe- 
tersburgu oraz europejską agendą UNESCO. Recenzent zna i wysoko ceni zarówno działalność naukową samego petersburskiego akademickiego centrum edukacji dorosłych, jak i jakość wydawanych przezeń książek i czasopism (czemu dawał już kilkukrotnie wyraz na łamach polskich i zagranicznych czasopism*).

Wszystko to powoduje, że w niniejszej recenzji jej autor nie odczuwa potrzeby szerszego odnoszenia się do wartości merytorycznej poszczególnych rozdziałów, gdyż ta została już potwierdzona i zagwarantowana już wcześniej - czy to przez wymagające międzynarodowe zespoły redaktorów i recenzentów, czy to np. przez procedury recenzyjne stosowane w „Roczniku Andragogicznym". Na pytanie czy Autorkom udało się powiązać wcześniej opublikowane teksty w spójną całość? - należy odpowiedzieć twierdząco. Całość bowiem przygotowano w ośmiu logicznie powiązanych ze sobą rozdziałach, poruszających kolejne wątki tytułowej problematyki:

I. Edukacja ustawiczna w dokumentach oświatowych Unii Europejskiej (s. 9-19).

II. Szkolnictwo wyższe w Europie i w Polsce w procesie edukacji ustawicznej (s. 20-29).

III. Europejska i Krajowa Rama Kwalifikacji dla uczenia się przez całe życie (s. 30-48).

IV. Studia podyplomowe w procesie edukacji ustawicznej (s. 49-55).

V. Walidacja efektów uczenia się jako nowe narzędzie edukacji ustawicznej (s. 56-63).

VI. Interesariusze zewnętrzni uczelni w edukacji ustawicznej (s. 64-69).

VII. Internacjonalizacja uczelni a edukacja ustawiczna (s. 70-76).

VIII. Edukacja ustawiczna w szkolnictwie wyższym wybranych krajów świata (s. 77-86).

Ze względu na podręcznikowy charakter całości za ważne uzupełnienie poszczególnych rozdziałów należy uznać, umieszczony na końcu każdego z nich, wykaz zalecanej dla danego zagadnienia literatury. Warte podkreślenia jest także umieszczenie przez Autorki w drugiej części Wprowadzenia

* $\quad$ Por. np.: T. Maliszewski, Lifelong Education - Vol. 8 / Образование через Всю Жизнь” - Том 8, Saint Petersburg 2010: Rosyjski rocznik edukacji dorostych. Rec.: „Rocznik Andragogiczny” 2010, s. 410-412; idem, Непрерывное образование для устойчивого развития. Труды международного сотрудничества, под ред. Н.А. Лобанова и В.Н. Скворцова. Образование через всю жизнь, том 7, Санкт-Петербург 2009. Rec.: „Edukacja Ustawiczna Dorosłych” 2011, nr 2(73), s. 168-170; idem, Новейшие результаты российско-польского сотрудничества в области непрерывного образования и андрогогике, „Вестник Ленинградского государственного университета им. А. С. Пушкина” 2012, № 1, Том 3: „Педагогика”, Санкт-Петербург 2012, с. 170-175. 
słowniczka podstawowych terminów z zakresu szeroko rozumianej edukacji ustawicznej, wraz z podaniem angielskich odpowiedników poszczególnych zwrotów (s. 6-8).

Konkludując, wydany przez Uniwersytet Jana Kochanowskiego podręcznik akademicki pt. Polityczno-oświatowy wymiar edukacji ustawicznej w szkolnictwie wyższym autorstwa Ewy Kuli i Marzeny Pękowskiej niewątpliwie zasługuje na uwagę. Stanowi bowiem wartościowy materiał dydaktyczny jako źródło wiedzy (ważnej dla studentów i innych członków społeczności akademickiej) o implementacji idei edukacji ustawicznej do szkolnictwa wyższego oraz miejscu uczelni wyższych w edukacji całożyciowej współczesnych Polaków (i Europejczyków).

Tomasz Maliszewski 